Rev. Mus. Argentino Cienc. Nat., n.s.

20(1): 83-90, 2018

ISSN 1514-5158 (impresa)

ISSN 1853-0400 (en línea)

\title{
The enigma of the Yepes' armadillo: Dasypus mazzai, $D$. novemcinctus or D. yepesi?
}

\author{
Agustín M. ABBA ${ }^{1}$, Guillermo H. CASSINI ${ }^{2,3}$, Juan I. TÚNEZ ${ }^{4}$ \& Sergio F. VIZCAÍNO ${ }^{5}$
}

\begin{abstract}
${ }^{1}$ Centro de Estudios Parasitológicos y de Vectores, CONICET, UNLP. Boulevard 120 s/n entre 60 y 64 (1900) La Plata, Buenos Aires, Argentina. ${ }^{2}$ División Mastozoología, Museo Argentino de Ciencias Naturales "Bernardino Rivadavia”, CONICET. Av. Ángel Gallardo 470, C1405DJR Buenos Aires, Argentina. ${ }^{3}$ Departamento de Ciencias Básicas, Universidad Nacional de Luján (UNLu), Ruta Nacional 5 y Av. Constitución s/n, (6700) Luján, Buenos Aires, Argentina. ${ }^{4}$ Grupo de Investigación en Ecología Molecular, Instituto de Ecología y Desarrollo Sustentable (INEDES-CONICET-UNLu), Ruta Nacional 5 y Av. Constitución s/n, (6700) Luján, Buenos Aires, Argentina. ${ }^{5}$ División Paleontología Vertebrados, Unidades de Investigación Anexo Museo FCNyM-UNLP, Av. 60 y 122, 1900, La Plata, Argentina. CONICET -La Plata.
\end{abstract}

\begin{abstract}
The long-nosed armadillos of the Dasypus genus are the richest and more widespread extant xenarthra. In 1933, the prominent Argentinean mammalogist José Yepes studied specimens collected by Salvador Mazza and named a new species: D. mazzai. Several authors interpreted that the holotype of the species was a juvenile of $D$. novemcinctus. In 1995, Vizcaíno support the synonymy with $D$. novemcinctus but accepted the existence of an endemic species of northwestern Argentina that dedicated to Yepes (D. yepesi). Morphological studies have questioned the synonymy of the species with $D$. novemcinctus. In this contribution we reviewed the identity of the type material by sequencing a DNA fragment of $212 \mathrm{bp}$, product of the $16 \mathrm{~S}$ ribosomal unit of Dasypodidae. Both samples of the holotype (bone and muscle) and of a specimen from the north of Santa Fe province have a $100 \%$ similarity with the D. yepesi / D. sabanicola sequences available in the GenBank. These results indicate that the type specimen of $D$. mazzai is neither a $D$. novemcinctus nor another species of the Dasypus genus previously named. Dasypus mazzai is revalidated and the eastern boundary in the Chaco region is confirmed. Field work is required to confirm the conservation status and current distribution of this endemic mulita.
\end{abstract}

Key words: Argentina, Chaco region, long nosed armadillo, Salta, Santa Fe, Yungas region.

Resumen: El enigma de la mulita de Yepes: Dasypus mazzai, D. novemcinctus o D. yepesi?. Las mulitas del género Dasypus representan el género más rico y ampliamente distribuido de los xenartros actuales. En 1933 el destacado mastozoólogo José Yepes estudió los especímenes colectados por Salvador Mazza y nominó una nueva especie: D. mazzai. Varios autores interpretaron que el holotipo era un ejemplar juvenil de D. novemcinctus. En 1995, Vizcaíno aceptó la sinonimia con $D$. novemcinctus, pero reconoció la existencia de una especie endémica del noroeste de Argentina que dedicó a Yepes (D. yepesi). Estudios morfológicos han cuestionado la sinonimia de esta especie con $D$. novemcinctus. En esta contribución se revisó la identidad del material tipo secuenciando un fragmento de $\mathrm{ADN}$ de $212 \mathrm{bp}$, que codifica parte de la unidad ribosomal 16S de Dasypodidae. Ambas muestras del holotipo (hueso y músculo) y de un espécimen del norte de la provincia de Santa Fe presentan $100 \%$ de similitud con secuencias de $D$. yepesi/D. sabanicola disponibles en el GenBank. Los resultados indican que el ejemplar tipo de $D$. mazzai no pertenece a $D$. novemcinctus ni a otra de las especies del género Dasypus previamente nominadas. Se revalida $D$. mazzai y se confirma el límite oriental de su distribución en la región chaqueña. Se requieren trabajos de campo para confirmar el estado de conservación y el rango de distribución actual de la especie.

Palabras clave: Argentina, Chaco, mulita, Salta, Santa Fe, Yungas.

\section{INTRODUCTION}

The long-nosed armadillos or "mulitas" belong to the Dasypodidae family, the earliest diverging clade inside the Cingulata by the middle Eocene (Gibb et al., 2016; Delsuc et al., 2016).
With seven species (see below), Dasypus is the extant xenarthra genera most diverse and more widespread (Wetzel et al., 2007; Hautier et al., 2017). The earliest record for the genus comes from the Late Pleistocene (Lujanian) of South America (Vizcaíno et al., 1995; Castro, 2015), but 
based on molecular evidence, Gibb et al. (2016) suggest that it must have radiated by the middle Miocene.

Morphologically, the genus is characterized by a long and slender rostrum, long ears, long tail and a smooth and a relatively bare carapace (except in $D$. pilosus which has a dense coat of hair that hides the carapace). Nowadays, Dasypus species occur from the southern United States to center of Argentina (Wetzel et al., 2007; Abba et al., 2012; Loughry \& McDonough, 2013). Six species are clearly recognized (but see Feijó et al., 2018): the seven-banded armadillo ( $D$. septemcinctus Linnaeus, 1758), the nine-banded armadillo ( $D$. novemcinctus Linnaeus, 1758), the southern long-nosed armadillo (D. hybridus Desmarest, 1804), the northern long-nosed armadillo (D. sabanicola Mondolfi, 1968), all belonging to the subgenus Dasypus (Wetzel \& Mondolfi, 1979); the greater long-nosed armadillo (D. kappleri Krauss, 1862), assigned to its own subgenus Hyperoambon (Wetzel \& Mondolfi, 1979); and the hairy long-nosed armadillo ( $D$. pilosus Fitzinger, 1856), assigned to the subgenus Cryptophractus, which has been recently proposed to raise to genus level (Castro et al., 2015). The identity of a seventh taxon has been the subject of discussion over more than seventy years.

In 1933, the prominent Argentinean mammalogist José Yepes (1897-1976) named and described Dasypus mazzai Yepes, 1933. The specimens that Yepes used for the original description of this armadillo were donated by the physician and epidemiologist Salvador Mazza (1886-1946), well-known for his studies in several endemic diseases of South American. During the Regional pathologies study mission, carried on in 1926 in the north of Argentina, Mazza, who had installed his laboratory in a railway car, focused on different potential vectors of trypanosomiasis (Chagas-Mazza disease). In doing so, he gathered a notable collection of mammals currently housed in the Mammalogy Section of the Museo Argentino de Ciencias Naturales "Bernardino Rivadavia" of Buenos Aires (MACN-Ma). Among them the armadillos are particularly conspicuous (see Abba \& Vizcaíno, 2008).

Hamlett (1939) interpreted that part of the material referred to $D$. mazzai by Yepes actually belonged to a new species that had to be named and based on the scarce specimens available, added a few more distinctive features. According to Hamlett (1939), Yepes was aware of the issue and reexamined the material. This work was never published but, D. mazzai continued to be accept- ed in general systematic compilations (Cabrera, 1957; Olrog, 1976, 1979)

In their exhaustive revision of the long nosed armadillos, Wetzel \& Mondolfi (1979) tried to reconstruct the history of the collections numbers of the specimens assigned to $D$. mazzai by Yepes. They concluded that " $D$. mazzai is a composite, a junior synonym of $D$. novemcinctus and $D$. hybri$d u s$ and that use of $D$. mazzai may also infringe upon D. septemcinctus" Wetzel \& Mondolfi (1979: 55). It should be clarified here, that the specimen MACN-Ma 31.213 that Yepes (1933) quote in the page 229 is not the Holotype of $D$. mazzai, but the holotype of Chlamyphorus truncatus patquiensis described by Yepes (1939), so this was a simple mistake in Yepes (1933).

In 1995 Vizcaíno revised the holotype and paratype of $D$. mazzai and compared with new specimens collected by him using numerical techniques to analyze the variation observed (Vizcaíno, 1995). In each analysis performed the specimens studied appeared well differentiated from other species of the genus. As a consequence, Vizcaíno named a new species, Dasypus yepesi, dedicating the species to Dr. J. Yepes, to whom he considered corresponded the merit of having noticed the morphological separation of this taxon with respect to those previously recognized. The type specimen was housed in the Museo de La Plata (MLP).

Recently, based on the evidence available in the literature Feijó \& Cordeiro-Estrela (2014) claimed that the holotype $D$. mazzai is not a juvenile of $D$. novemcinctus and, hence, that $D$. mazzai is a valid species, with $D$. yepesi as a junior synonym. Gibb et al. (2016) described a DNA sequence of a specimen of the type series D. yepesi as possessing very similar mitogenomes to $D$. sabanicola. A recent morphometric analysis of long-nosed armadillos by Hautier et al. (2017) did not include D. mazzai-D. yepesi. Finally, the most recent morphometric analyses of Dasypus genus by Feijó et al. (2018) support the validity of D. mazzai.

In the $90^{\text {th }}$ anniversary of the incorporation of José Yepes to the Mammalogy Section of the Museo Nacional (today Museo Argentino de Ciencias Naturales "Bernardino Rivadavia") (see Garcia, 2018), and like other colleagues (Galliari, 2018; Ojeda et al., 2018; Gonzalez et al., 2018), we aimed to honored to J. Yepes. The goal of our work is to test the identity of the holotype of $D$. mazzai (MACN-Ma 31.273) using molecular tools. 


\section{MATERIALS AND METHODS}

\section{Specimens}

Dasypus

mazzai: MACN-Ma

31.273

(Holotype, Fig. 1. A-B); Supp. Matterial 1) a cephalic shield, carapace and tail, body (without head) conserved in fluid, skull figured in Yepes (1933) lost. Locality: Argentina, Salta, Dto. Orán, Tabacal (Fig. 2), collected by Salvador Mazza on October 1931. Sample for DNA analyses includes a muscular tissue on fluid and a bone sample from caudal vertebras dried on the tail. MACNMa 13222 (Paratype, Fig. 1. C-D; Supp. Material 2) a mounted skin, figured by Yepes (1933), the skull number JVY 32 actually lost (Figure 2B). Locality: According to Yepes (1933) Argentina, Salta, Dto. Orán, Tabacal (Fig. 2). Collected by Salvador Mazza. Vizcaíno (1995) considered it unknown, because that was the town where Mazza labeled the specimens collected by the inhabitants of the area, so that it cannot accurately determine where the specimen came from. Sample for DNA analyses includes dry tissue in the tail from the mounted skin.

Dasypus hybridus: MACN-Ma 30.17 and 30.18, carapace and skull. Locality: Argentina, Chaco, Pampa del Indio (Fig. 2). Collected by Jorge G. Dennler on January 1930. MACN-Ma 33.176, carapace and skull. Locality: Argentina, Santa Fe, Dto. General Obligado, Villa Guillermina (Fig. 2), Collected by Cecilio Romaña. MACN-Ma 36.980 , carapace without locality data collected by Salvador Mazza (field number 45775). All samples for DNA analyses include dry muscular tissue attached on the inner carapace.

Dasypus novemcinctus: MACN-Ma 27796 (DanoFPLM), Female. Locality: Argentina, Formosa, Pirane, La Marcela. Collected by A. M. Abba on June 3, 2016. DanoCLI Adult female. Locality: Argentina, Corrientes, Laguna Iberá (GPS: 28.546945 S; 59.19597 O). Collected by A. M. Abba on December 1, 2008. DanoCMC. Locality: Argentina, Corrientes, Monte Caseros, Ruta 14. Collected by A. M. Abba on December 4, 2008. DanoFTM. Locality: Argentina, Formosa, Tres Mojones, Est. Nupira. Collected by A.M. Abba on December 30, 2012 (Fig. 2). With the exception of MACN-Ma 27796 specimen (muscular tissue), all samples for DNA analyses include ear biopsy of captured and released living animals.

\section{DNA sequence}

We choose a 16s rRNA of 212 bp length in which $D$. novemcinctus, $D$. hybridus and $D$. yepesi have three different haplotypes determined by

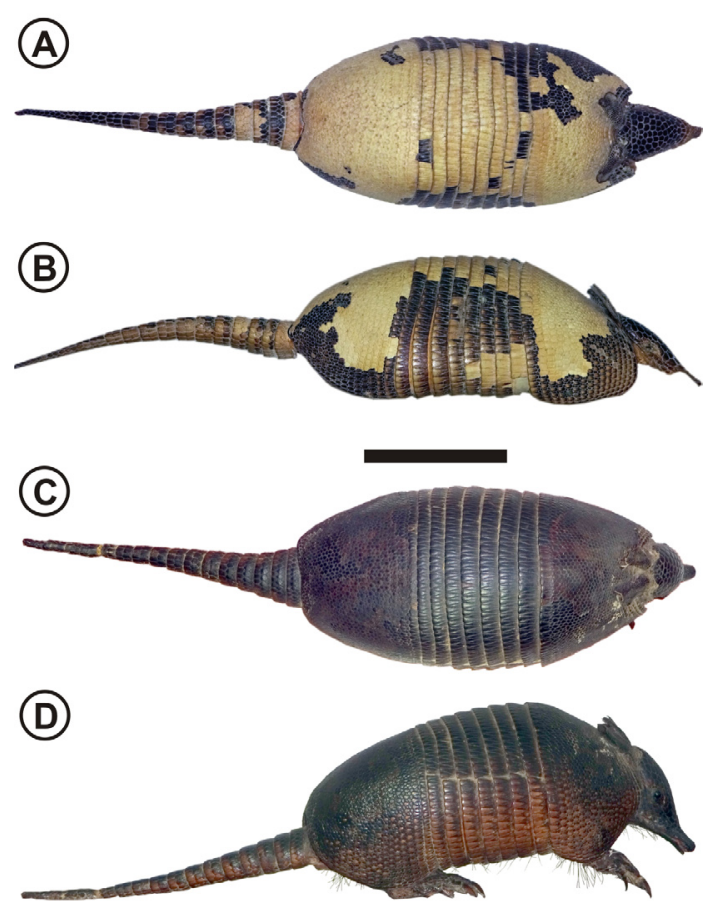

Fig. 1. Cephalic shield, carapace and tail of specimen MACN-Ma 31.273, Holotype of D. mazzai Yepes, 1933 in dorsal norm (A) and right lateral norm (B). Mounted skin of specimen MACN-Ma 13222 Paratype of D. mazzai in dorsal norm (C) and right lateral norm (D). Scale bar $=10 \mathrm{~cm}$.

15 variable sites. The two sequences of $D$. novemcinctus available in the GenBank (KT818542.1 from French Guiana and Y11832 from USA) present a percentage of differentiation of $2 \%$ for the Dasypodidae 16S ribosomal RNA (16S rRNA). This differentiation is less than that presented by most of the sequences belonging to the different species studied. However, this high differentiation inside $D$. novemcinctus could be reflecting the differentiation of two geographical lineages, of perhaps two different species (see Gibb et al., 2016). In order to evaluate the variability in the sequenced fragment we included four specimens of $D$. novemcinctus from Argentina in the analysis (see above). In addition, the sequences of $D$. hybridus (GenBank KT818540) and D. septemcinctus (GenBank KT818546) show a similarity of $100 \%$ for the chosen fragment. Gibb et al. (2016) found that this two mitogenome sequences have a $99.3 \%$ identity and referred as probably misidentification. Indeed, the $D$. septemcinctus sequence belongs to an animal collected in north Argentina and up to date there as a wide amount of evidence that this species is absent from this 


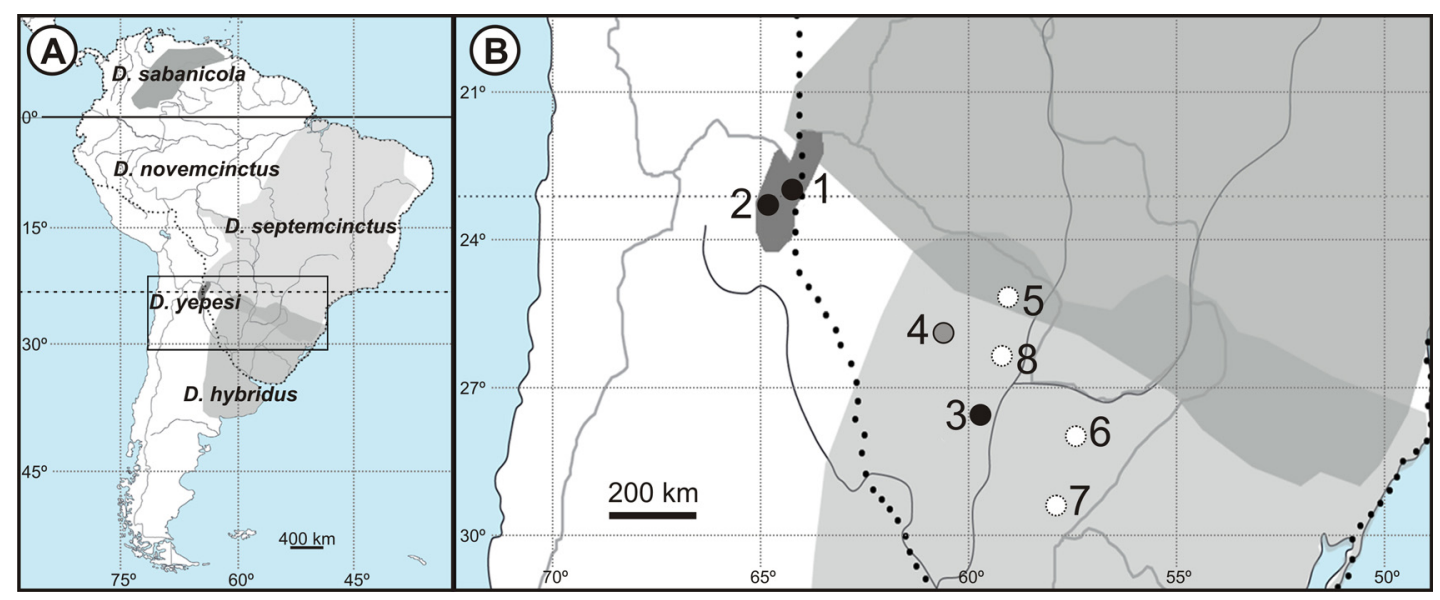

Fig. 2. (A) Map showing the distribution of the Dasypus species cited in this paper. In different grays shows the distribution of $D$. sabanicola, $D$. septemcinctus, $D$. yepesi and $D$. hybridus, and with line point shows the limit of $D$. novemcinctus distribution. (B) Detail of the area that comprise this study and localities of principal specimens. 1- Holotype and Paratype of D. mazzai (black dot, Argentina, Salta, Dto. Orán, Tabacal, MACN-Ma 31.273 and 13222 respectively), 2- Type locality D. yepesi (black dot, Argentina, Salta, Dto. Orán, San Andrés, MLP 30.III.90.8), 3- D. mazzai (black dot, Argentina, Santa Fe, Dto. General Obligado, Villa Guillermina, MACN-Ma 33.176), 4- D. hybridus (grey dot, Argentina, Chaco, Pampa del Indio, MACN-Ma 30.17 and 30.18), and four specimens of $D$. novemcinctus from Argentina (white dots), 5- MACN-Ma 27796 (Formosa, Pirane, La Marcela), 6DanoCLI (Corrientes, Laguna Iberá), 7- DanoCMC (Corrientes, Monte Caseros, Ruta 14), 8 - DanoFTM (Formosa, Tres Mojones, Est. Nupira).

country (Abba \& Vizcaíno, 2008; Abba et al., 2012). Based on morphologic and morphometric analysis, Feijó et al. (2018) proposed that D. hybridus and D. septemcinctus are synonyms but this assignation is uncertain until have been a support by a robust molecular analysis.

\section{Mitochondrial DNA extraction and PCR amplification}

The first steps of DNA extraction protocols differed depending on the sample source. Dried tissue samples were incubated overnight at $37^{\circ} \mathrm{C}$ in extraction buffer containing $10 \mu \mathrm{l}$ of proteinase $\mathrm{K}, 10 \mathrm{mg} / \mathrm{ml} ; 5 \mu \mathrm{l}$ of RNase, $20 \mathrm{mg} / \mathrm{ml}$ and $10 \%$ SDS. For bone samples, approximately $50 \mathrm{mg}$ of bone powder was incubated with stirring for 24 hours in $1 \mathrm{ml}$ of EDTA $0.5 \mathrm{M}, \mathrm{pH}=8$. The mix was then centrifuged for $10 \mathrm{~min}$ at $14,000 \mathrm{rpm}$ and the precipitate was stored for the posterior extraction and purification of DNA. The sample stored in formaldehyde was first washed in $70 \%$ ethanol for $30 \mathrm{~min}$ and then incubated with stirring for $24 \mathrm{hs}$ in $\mathrm{TE}$ buffer at $37^{\circ} \mathrm{C}$, replacing the buffer every 8 hours. After these first steps, DNA was isolated from all samples by phenol-chloroform extraction and alcohol precipitation.

Aliquots of total DNA were used as templates in Polymerase Chain Reaction (PCR) in order to amplify a $212 \mathrm{bp}$ double-stranded DNA product from the Dasypodidae 16S rRNA mitochondrial gene. Each PCR had a reaction volume of $20 \mu \mathrm{l}$ and contained 1X Easy Taq buffer $(20 \mathrm{mM}$ Tris$\mathrm{HCl}, \mathrm{pH}=8.3,20 \mathrm{mM} \mathrm{KCl}, 10 \mathrm{mM} \mathrm{NH} 4_{2} \mathrm{SO}_{4}$, $2 \mathrm{mM} \mathrm{MgS0}{ }_{4}$ ), $0.4 \mathrm{mM}$ of each deoxynucleotide triphosphate, $0.5 \mu \mathrm{M}$ of forward and reverse primers, $0.5 \mathrm{U}$ of Easy Taq DNA polymerase (TransGen Biotech), $3.5 \mathrm{mM} \mathrm{MgCl}, 2 \mu \mathrm{g} / \mu \mathrm{l} \mathrm{BSA}$ (New England Biolabs), $4 \mu \mathrm{l}$ of DNA extract and water to reach the final volume reaction. The primer pair used was, arm16SF (5'-TAAGTAGAGGTGAAAG ACCAAC -3') and arm16SR (5'-TGCTTTAGGCCAACTATGT-3'). It was developed using Primer3 online software using the complete sequences of the mitochondrial genome of $D$. hybridus, $D$. novemcinctus and $D$. yepesi as reference (GenBank: KT818540, KT818542, and KT818547, respectively). We chose this short DNA fragment due to the difficulty to amplify longer fragments from old bone and tissue sample and because it contains several variable sites that allow the distinction of the species to which the studied samples could belong (see above). Amplification protocol consisted in a single denaturation step at $94^{\circ} \mathrm{C}$ for $4 \mathrm{~min}$, followed by 20 cycles of denaturation at $94^{\circ} \mathrm{C}$ for $30 \mathrm{~s}$, annealing at $43^{\circ} \mathrm{C}$ (annealing temperature $-5^{\circ} \mathrm{C}$ ) for $30 \mathrm{~s}$, and extension at $72^{\circ} \mathrm{C}$ for $30 \mathrm{~s} ; 20$ cycles of denaturation at $94^{\circ} \mathrm{C}$ for $30 \mathrm{~s}$, annealing at $48^{\circ} \mathrm{C}$ 


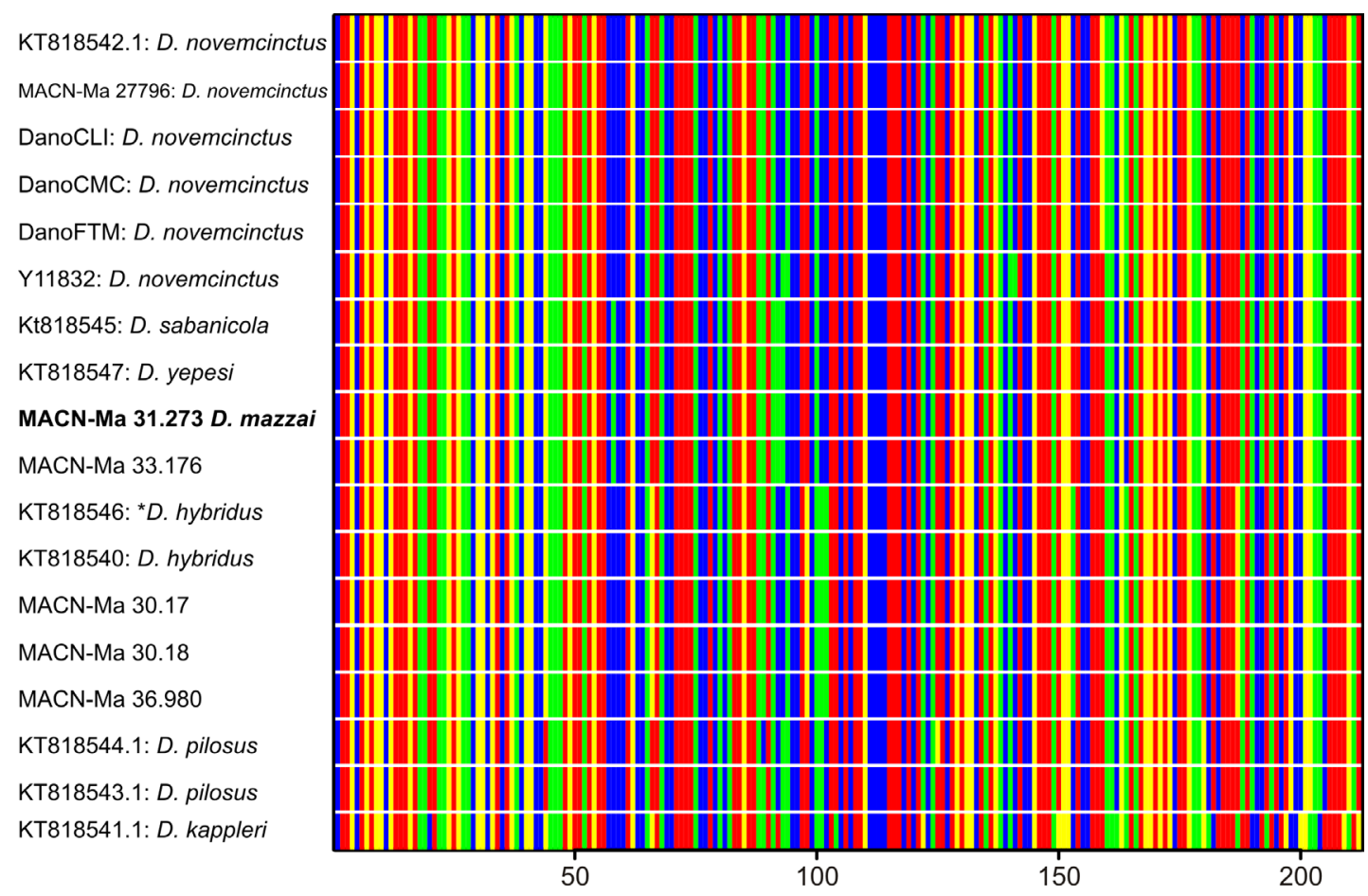

Fig. 3. Alignment of the $212 \mathrm{bp}$ fragment of the $16 \mathrm{~S}$ ribosomalRNA mitochondrial gene amplified from museum specimens and GenBank sequences. First base of museum specimen sequences corresponds to position 1421 in the Dasypus yepesi mtDNA complete genome (GenBank: KT818547). Color key: red A, yellow G, green C and blue T. Asterisk indicates the sequence here referred as D. hybridus. Holotype of D. mazzai in bold.

for $30 \mathrm{~s}$, and extension at $72^{\circ} \mathrm{C}$ for $30 \mathrm{~s}$ and a final extension at $72^{\circ} \mathrm{C}$ for $5 \mathrm{~min}$. PCR products were resolved in $1 \%$ agarose gel electrophoresis and visualized under UV light. A $10 \mu \mathrm{l}$ aliquot of the amplification products were purified using the EXO/SAP enzymatic method and sent to an external laboratory (Biotechnology Institute of INTA Castelar, Argentina) where sequencing was performed with the same primers used in PCR reactions in an ABI 377 Automated DNA PrismTM Sequencer (Applied Biosystems Inc).

\section{Data analyses}

Sequences were checked and manually edited using Chromas v.2.6.5 free software (www. technelysium.com.au/chromas.htm), aligned in MEGA 7 (Kumar et al., 2016) and compared with those sequences previously published for the Dasypodidae family (Genbank: KT81854047 and Y11832) using the nucleotide BLAST online tool (https://blast.ncbi.nlm.nih.gov/Blast. cgi) and registering their identity percentages.

\section{RESULTS}

Ten of the eleven samples analyzed could be amplified and sequenced successfully (Table 1; Fig. 3; Suppl. Material 3). The amplified 16s rRNA fragments obtained had a length of $212 \mathrm{bp}$ and consisted in three haplotypes determined by 15 variable sites (Table 1 ). These haplotypes were compared with those 16S rRNA sequences previously published for the Dasypodidae family (Figure 3). The four $D$. novemcinctus samples analyzed showed a $100 \%$ similarity with $D$. novemcinctus GenBank sequence KT818542.1 (Table 1), a 98\% similarity with $D$. novemcinctus GenBank sequence Y11832.1 and 93-97\% similarity with 16S rRNA sequences from other Dasypodidae species. Samples MACN-Ma 31.273 ( $b=$ bone), MACNMa $31.273(t=$ tisuue $)$ and MACN-Ma 33.176 showed a $100 \%$ similarity with D. yepesi and $D$. sabanicola sequences (Genbank: KT818547 and KT818545, respectively; Table 1) and a 95-97\% similarity with 16S rRNA sequences from other Dasypodidae species, suggesting that these individuals belong to the species $D$. yepesi/sabanicola. Instead, samples MACN-Ma 30.17, 30.18 and 
Table 1. Haplotypes and relative position of variable nucleotides in the $212 \mathrm{bp}$ fragment of the $16 \mathrm{~S}$ ribosomal RNA mitochondrial gene amplified from museum specimens. Haplotype A: GenBank KT818545 (D. sabanicola) and KT818547 (D. yepesi). Haplotype B: GenBank KT818540 and KT818546 (D. hybridus). Haplotype C: GenBank KT818542 (D. novemcinctus). * First base of museum specimen sequences corresponds to position 1421 in the KT818547 mtDNA complete genome.

\begin{tabular}{|c|c|c|c|c|c|c|c|c|c|c|c|c|c|c|}
\hline \multirow{2}{*}{ Hap. } & \multirow{2}{*}{$\begin{array}{l}\text { Collection. } \\
\text { number }\end{array}$} & \multicolumn{13}{|c|}{$\underline{\text { Relative position of variable nucleotides* }}$} \\
\hline & & 58 & 66 & 92 & 93 & 94 & 98 & 101 & 102 & 153 & 164 & 180 & 187 & 192 \\
\hline $\mathrm{A}$ & $\begin{array}{l}31.273(\mathrm{~b}) \\
31.273(\mathrm{t}) \\
33.176\end{array}$ & $\mathrm{C}$ & A & $\mathrm{C}$ & $\mathrm{C}$ & $\mathrm{T}$ & $\mathrm{A}$ & $\mathrm{T}$ & $\mathrm{T}$ & A & $\mathrm{T}$ & G & A & $\mathrm{C}$ \\
\hline B & $\begin{array}{l}30.17 \\
30.18 \\
36.980\end{array}$ & $\mathrm{~T}$ & G & $\mathrm{T}$ & $\mathrm{T}$ & $\mathrm{C}$ & G & $\mathrm{C}$ & $\mathrm{C}$ & $\mathrm{C}$ & $\mathrm{C}$ & A & G & $\mathrm{T}$ \\
\hline $\mathrm{C}$ & $\begin{array}{l}27796 \\
\text { DanoCLI } \\
\text { DanoCMC } \\
\text { DanoFTM } \\
\end{array}$ & $\mathrm{T}$ & A & $\mathrm{T}$ & $\mathrm{T}$ & $\mathrm{C}$ & A & $\mathrm{T}$ & $\mathrm{T}$ & $\mathrm{T}$ & G & $\mathrm{C}$ & A & A \\
\hline
\end{tabular}

MACN-Ma 36.980 showed a $100 \%$ similarity with D. hybridus sequences (Genbank: KT818540 and KT818546, respectively; Table 1) and a 95-97\% similarity with 16S rRNA sequences from other Dasypodidae species, suggesting that these three individuals belong to $D$. hybridus. Finally, the sample MACN-Ma 13222 presented sequences of very low quality that prevented to identify the species to which they belong.

\section{DISCUSSION}

The four specimens of $D$. novemcinctus from Argentina show no variation in the amplified 16s rRNA fragments and share the same sequence with the Gibb et al. (2016) specimen from French Guiana (GenBank KT818542). In addition, this sequence has a $98 \%$ of similarity with the Arnason et al. (1997) from USA (GenBank Y11832). The divergence between the French Guiana and USA lineages was already established since Huchon et al. (1999) study. Further studies are needed to confirm that the specimens from French Guiana and Argentina belong to the same lineage. If this is the case, as the type locality for $D$. novemcinctus corresponds to "America Meridionali" (i.e., South America) and restricted to Pernambuco, Brazil, by Cabrera (1957: p. 225; see also Feijó et al., 2018), the USA lineage might represent a previously unrecognized taxon.

Our results indicate that the holotype of $D$. mazzai (MACN-Ma 31.273) is not a specimen of $D$. novemcinctus (neither the South American nor USA lineages) as proposed by Hamlett (1939), Wetzel \& Mondolfi (1979) and Vizcaíno (1995), nor any other of the Dasypus species previously nominated. Consequently, D. mazzai must be considered a valid species as originally described by Yepes (1933). Furthermore, the sequences of the holotype of D. mazzai are identical to that of one the specimens of the hypodigm of D. yepesi, housed in the Museo de La Plata (MLP 30.III.90.2). Thus, nowadays the specimens of D. mazzai are housed in the collections of the MACN and MLP.

The recognition of D. mazzai as a valid species has further taxonomic consequences for the systematics of the genus that remain to be tested. Following Gibb et al. (2016) the complete mitogenomic sequence of the specimen of D. yepesi Vizcaíno, 1995 (MLP 30.III.90.2), show $98.7 \%$ identity with that of D. sabanicola Mondolfi, 1968 housed at National Museum of Natural History, Washington, USA (USNM 372834). Therefore if D. sabanicola and D. yepesi were considered the same species, D. sabanicola would be a junior synonym of $D$. mazzai Yepes, 1933. This opens an interesting distributional issue, because the same species would be represented by populations restricted to very distinct localities of South America, with a separation at least of $3000 \mathrm{~km}$ : the llanos of Venezuela and Colombia and in Northern Argentina. Further studies are needed to understand this possibly disjunct distribution.

Yepes (1933) stated that the type locality of D. mazzai in the Argentinean Yungas represents the western limit of its distribution, which extended eastwards to the North of Santiago del Estero and Santa Fe provinces, in the Chaco region. The identification of the sequence of the specimen MACN-Ma 33.176 (assigned to D. hybridus by Feijó \& Cordeiro-Estrela 2014) from Villa Guillermina, Santa Fe (General Obligado 
Department) as belonging to D. mazzai confirms the distributional range of $D$. mazzai in the Chaco region of Argentina (Fig. 2) proposed in the 1930's. As Yungas and the Chaco regions extended in the neighbor countries of Paraguay and Bolivia, the species could be present there too, which makes the distribution of $D$. mazzai needs to be updated.

Other Dasypus species reported in the distribution area of $D$. mazzai are $D$. novemcinctus, $D$. hybridus and probably D. septemcinctus (Wetzel $\&$ Mondolfi, 1979). Yepes (1933) used the MACNMa 30.17 and 30.18 specimens as D. septemcintus in his cranial measurement comparison with those of the Holotype and Paratype of D. mazzai (both actually lost). Wetzel \& Mondolfi (1979) assigned one of them to D. septemcinctus (MACNMa 30.18) and the other to D. hybridus (MACNMa 30.17) based on their canonical analyses of cranial measurements. Following Wetzel \& Mondolfi (Page 54, 1979), the evidence of sympatry between both species in the Chaco region of Argentina was based in few specimens (including both before mentioned). In this work we follow the criteria of Gibb et al. (2016) and considered the sequence of $D$. septemcinctus ISEM T-3002 (Genbank: KT818546) from Argentina as misidentification, and considered it as belonging to D. hybridus. According the morphological characters and the DNA sequences of the specimens MACN-Ma 30.17, MACN-Ma 30.18 and MACNMa 36.980 we assign them to $D$. hybridus.

The DNA extraction using old samples (from 1930 decade) allowed us to evaluate the taxonomic assignation of Dasypus species from Yungas and Chaco of Argentina. These two forested regions are actually among the more degraded areas in the world (Malizia et al., 2012, Kuemmerlet et al., 2017). In addition, there are very poor data about conservation status, distribution, abundance and other biological parameters of the Dasypus armadillos inhabiting these regions. Their conservation status is quite preoccupant. Dasypus hybridus and D. sabanicola are catalogued as Near Threatened due to severe habitat loss and hunting throughout its range (Abba \& Gonzales, 2014, Superina et al., 2014) and " $D$. yepesi" is catalogued as Data Deficient (Abba \& Vizcaíno, 2014). A reassessment of the conservation status of these species is highly needed, which encourages performing new field efforts to acquire new data of distribution and current population status of the Dasypus species in these regions.

As a closing remark, we regret that Yepes no longer has an armadillo nominated after him. However, we understand that our impartial scientific results honor his work and his intention to pay homage to Dr. Salvador Mazza, by recognizing the correctness of his original identification of an endemic armadillo from northern Argentina.

\section{CONCLUSIONS}

The S16 rDNA sequences of the Holotype of Dasypus mazzai Yepes, 1933 MACN-Ma 31.273 are not compatible with the specimens of Dasypus novemcinctus from South America and USA and must be considered as corresponding to a different taxa.

The specimen MACN-Ma 33.176 from Villa Guillermina, Santa Fe province (General Obligado Department) belongs to D. mazzai and confirms the distributional range in the Chaco region of Argentina as was supposed by Yepes (1933).

\section{ACKNOWLEDGMENTS}

We want to thank the invitation to contribute in this tribute to J. Yepes in the $90^{\text {th }}$ anniversary of his incorporation to the Museo staff. To P. Teta and S. Lucero for guarantying access to the MACN specimens and catalogues books, and E. Ibañez, D. Peralta and M. Nardelli for their collaboration in DNA analyses. The comments and corrections by P. Teta and the reviewers greatly enhanced this manuscript. This work is a contribution to the projects PICT 2016-2665 (ANPCyT), Universidad Nacional de Luján CDD-CB 430/09 and № 372/13 (Fondos Finalidad 3.5).

\section{BIBLIOGRAPHY}

Abba, A.M. \& S.F. Vizcaíno. 2008. Los xenartros (Mammalia: xenarthra) del Museo Argentino de Ciencias Naturales "Bernardino Rivadavia" y del Museo de La Plata (Argentina). Contribuciones del MACN 4:5-37.

Abba, A.M., M.F. Tognelli, V.P. Seitz, J.B. Bender \& S.F. Vizcaíno. 2012. Distribution of extant xenarthrans (Mammalia: Xenarthra) in Argentina using species distribution models. Mammalia 76:123-136.

Anacleto, T.C.S., Smith, P., Abba, A.M. \& M. Superina. 2014. Dasypus septemcinctus. The IUCN Red List of Threatened Species 2014: e.T6293A47441509. http://dx.doi.org/10.2305/IUCN.UK.2014-1.RLTS. T6293A47441509.en.

Arnason, U., A. Gullberg, \& A. Janke.1997. Phylogenetic analyses of mitochondrial DNA suggest a sister group relationship between Xenarthra (Edentata) 
and Ferungulates. Molecular Biology and Evolution. 14 (7), 762-768.

Cabrera, A. 1957. Catálogo de los mamíferos de América del Sur. Revista del Museo Argentino de Ciencias Naturales "Bernardino Rivadavia", Zool. 4: 1-307.

Castro, M.C., M.R. Ciancio, V. Pacheco, R.M. SalasGismondi, J.E. Bostelmann \& A.A. Carlini. 2015. Reassessment of the hairy long-nosed armadillo "Dasypus" pilosus (Xenarthra, Dasypodidae) and revalidation of the genus Cryptophractus Fitzinger, 1856. Zootaxa 3947 (1): 030-048.

Delsuc, F, G.C. Gibb, M. Kuch, G. Billet, L. Hautier, J. Southon, J. Rouillard, J.C. Fernicola, S.F. Vizcaíno, R.D.E. MacPhee \& H.N. Poinar. 2016. The phylogenetic affinities of the extinct glyptodonts. Current Biology 26, R141-R156.

Galliari, F.C. 2018. Secuencias de osificación y heterocronía en los miembros de los armadillos Dasypus y Chaetophractus (Mammalia, Xenarthra, Cingulata). Revista del Museo Argentino de Ciencias Naturales, Nueva Serie. 20(1): 91-107. Doi: 10.22179/ REVMACN.20.562

García, S.V. 2018. La trayectoria del zoólogo José Yepes: colecciones, viajes y zoogeografía en las décadas de 1930 y 1940. Revista del Museo Argentino de Ciencias Naturales, Nueva Serie. 20(1): 71-81. Doi: 10.22179/REVMACN.20.579

González, S., A.M., Bonfim Mantellatto \& J.M. Barbanti Duarte. 2018. Craniometrical differentiation of gray brocket deer species from Brazil. Revista del Museo Argentino de Ciencias Naturales, Nueva Serie. 20(1): 179-193. Doi: 10.22179/ REVMACN.20.561

Feijó, A. \& P. Cordeiro-Estrela. 2014. The correct name of the endemic Dasypus (Cingulata: Dasypodidae) from northwestern Argentina. Zootaxa 3887:8894

Feijó, A., B.D. Paterson \& P. Cordeiro-Estrela. 2018. Taxonomic revision of the long-nosed armadillos, Genus Dasypus Linnaeus, 1758 (Mammalia, Cingulata). PLoS ONE 13(4): e0195084. https://doi. org/10.1371/journal.pone.0195084

Gibb, G.C., F.L. Condamine, M. Kuch, J. Enk, N. Moraes-Barros, M. Superina, H.N. Poinar \& F. Delsuc. 2016. Shotgun mitogenomics provides a reference phylogenetic framework and timescale for living xenarthrans. Molecular Biology and Evolution 33(3):621-42.

Hamlett, G.W.D. 1939. Identity of Dasypus septemcinctus Linnaeus with notes on some related species.
Journal of Mammalogy 20: 328-336.

Hautier, L., G. Billet, B. de Thoisy \& F. Delsuc. 2017. Beyond the carapace: skull shape variation and morphological systematics of long-nosed armadillos (genus Dasypus). PeerJ 5:e3650; DOI 10.7717/ peerj.3650.

Kuemmerlet T. et al. 2017. Forest conservation: Remember Gran Chaco. Science 355: 465.

Kumar, S., G. Stecher \& K. Tamura. 2016. MEGA 7: Molecular Evolutionary Genetics Analysis Version 7.0 for Bigger Datasets. Molecular Biology and Evolution 33 (7): 1870-1874.

Loughry, W.J. \& C. M. McDonough. 2013. The ninebanded armadillo. University of Oklahoma Press, Norman.

Malizia, L., S. Pacheco, C. Blundo, \& A.D. Brown. 2012. Caracterización altitudinal, uso y conservación de las Yungas Subtropicales de Argentina. Ecosistemas 21: 53-73.

Ojeda, A.A., A.P. Tarquino-Carbonell, L.M. Vélez \& R.A. Ojeda. 2018. Tympanoctomys: 75 años de historia. Estado actual del género. Revista del Museo Argentino de Ciencias Naturales, Nueva Serie. 20(1): 109-122. Doi: 10.22179/REVMACN.20.556

Olrog, C. C. 1976. Sobre mamíferos de la selva húmeda. Acta Zoológica Lilloana 32: 5-12.

Olrog, C. C. 1979. Los mamíferos de la selva húmeda, Cerro Calilegua, Jujuy. Acta Zoológica Lilloana 33: 9-14.

Vizcaíno, S.F. 1995. Identificación específica de las "mulitas", género Dasypus L. (Mammalia, Dasypodidae), del noroeste argentino. Descripción de una nueva espécie. Mastozoología Neotropical 2 (1): 5-13.

Wetzel, R.M., A.L. Gardner \& K.H. Redford. 2007. Order Cingulata. En: A.L. Gardner (ed.), Mammals of South America, Volume 1: Marsupials, Xenarthrans, Shrews and Bats, pp. 128-156. The University of Chicago Press, Chicago.

Wetzel, R.M. \& E. Mondolfi. 1979. The subgenera and species of long-nosed armadillos, Genus Dasypus L. En: J.F. Eisenberg (ed.) Vertebrate ecology in the northern neotropics, pp. 39-63.The National Zoological Park, Smithsonian Institution, Washington,.

Yepes, J. 1933. Una nueva especie de "mulita" (Dasipodinae) para el norte argentino. Physis 11: 225-232.

Yepes, J. 1939. Una nueva subespecie de "pichiciego" mayor (Chlamyphorinae) y su probable distribución geográfica. Physis 16: 35-39. 